\title{
SURVEY KUALITAS LULUSAN JURUSAN PENDIDIKAN TEKNIK INFORMATIKA
}

\author{
Oleh \\ Gede Saindra Santyadiputra, Ketut Agustini \\ Jurusan Pendidikan Teknik Informatika, FTK, UNDIKSHA \\ gsaindras@undiksha.ac.id
}

\begin{abstract}
ABSTRAK
Tujuan jangka panjang yang ingin dicapai dari hasil penelitian ini adalah sebagai feedback atau masukan yang dapat memperbaiki kinerja Jurusan dalam hal mencetak tenaga ahli dalam bidang pendidikan teknik informatika maupun tenaga praktisi yang siap digunakan di lapangan. Target yang ingin dicapai dalam penelitian ini adalah untuk mengetahui kualitas lulusan jurusan Pendidikan Teknik Informatika terhadap pengguna lulusan. Metode yang digunakan dalam penelitian ini adalah survey deskriptif, dengan cara menghimpun data melalui angket yang disebar ke lulusan dan pengguna lulusan. Rencana kegiatan meliputi 1) identifikasi masalah, 2) merumuskan masalah, 3) menentukan tujuan dan manfaat penelitian, 4) menentukan studi pustaka/kajian teori, 5) mendesain metode penelitian, 6) pengambilan data yang diawali dengan menghubungi/koordinasi dengan alumni yang telah dipergunakan oleh pengguna lulusan (telah bekerja), 7) menganalisis data yang akan menghasilkan gambaran tentang kualitas lulusan di mata pengguna lulusan, dan yang terakhir 8) pembuatan laporan penelitian. Penelitian ini akan dilakukan di Jurusan Pendidikan Teknik Informatika selama 8 bulan. Hasil dari penelitian ini berupa gambaran tentang lulusan Jurusan Pendidikan Teknik Informatika di mata pengguna lulusan.

Berdasarkan respon dari pengguna lulusan terhadap kualitas lulusan secara menyeluruh, didapat bahwa kualitas lulusan berada pada rentangan baik. Hal ini dapat dilihat dari aspek lokasi bekerja, waktu tunggu kerja, penilaian lulusan terhadap aspekaspek pembelajaran yang dimiliki Jurusan PTI, relevansi kompetensi yang dimiliki lulusan terhadap kebutuhan dunia kerja, dan relevansi peran jurusan terhadap kompetensi yang dimiliki lulusan terhadap kebutuhan dunia kerja yang kesemuanya rata-rata pada rentangan baik.
\end{abstract}

Kata-kata kunci : penelitian survey, kualitas lulusan perguruan tinggi.

\begin{abstract}
Long-term goals to be achieved from this research is to be used as input or feedback for Department of Informatics Engineering Education (PTI). The feedback can improve performanceof department. This improve, in terms of produce expert or practitioners in the field of informatics engineering education that can be "ready for use" in the real world. The target to be achieved in this research is to determine the quality of graduates to the stakeholders. The method used in this research is descriptive survey method. This method is done by collecting data through questionnaires distributed to the graduates and stakeholders.Plan of the research activities include 1) identification problems, 2) formulate problems, 3) determining purpose and benefits of the research, 4) determines literature/study of theory, 5) designing research methods, 6) data collection that begins with a coordination with graduates who have been used by the stakeholders (have worked), 7) analyze data that will describe of the quality of graduates in the perspective of the stakeholders, and the last 8) producing final report.This research was conducted at the Department of Informatics Engineering Education for 8 months. The results of this research is a description of the graduates of the Department of Informatics Engineering Education in the perspective of the stakeholder.
\end{abstract}


The result of this research describe the quality of graduates are in a good range. The Results obtained from graduates and stakeholders questionnaires responses. Quality of graduates consist of work location, waiting time to get a job, stakeholder assessment associated withaspects of learning which owned by Department of Informatics Engineering Education, relevance of the competency of graduates and what stakeholders need, relevance of the competency of graduates and what stakeholders need, the relevance of the Department's role against competences of the graduates and what stakeholders needs. All of the aspects, in average, have a good value.

Keywords: survey research, quality of college graduates.

\section{PENDAHULUAN}

Berbicara masalah kualitas lulusan perguruan tinggi, tidak terlepas dari peran sistem yang terlibat dalam penumbuhkembangan kualitas individu tersebut. Terdapat dua faktor yang mempengaruhi kualitas lulusan yakni faktor internal sistem dan faktor eksternal sistem. Faktor internal sistem merupakan peran perguruan tinggi dalam mencetak lulusan yang berkualitas. Sedangkan faktor eksternal sistem adalah pengguna lulusan yang memberdayakan luaran dari perguruan tinggi. Berbagai cara ditempuh perguruan tinggi agar lulusannya memiliki kualitas, baik dari segi intelektualitasnya maupun kepribadiannya. Salah satunya dengan merefleksi diri terhadap lulusan-lulusan yang telah diberdayakan oleh faktor eksternal sistem, dalam hal ini adalah perusahaanperusahaan, instansi-instansi maupun organisasi sebagai pengguna lulusan. Refleksi ini sekaligus mengetahui respon dari pengguna lulusan terhadap kinerjanya. Hal ini memberikan informasi pemetaan kualitas lulusan suatu perguruan tinggi terhadap pengguna lulusan. Hasil dari pemetaan ini akan menjadikan suatu acuan terhadap perguruan tinggi untuk mempertahankan atau bahkan meningkatkan mutu pendidikannya (Mutaqin, 2009).

Jika perguruan tinggi dapat dianggap sebagai suatu jasa pelayanan terhadap konsumen, dalam hal ini perguruan tinggi memberikan jasa pelayanan berupa mencetak tenaga kerja siap pakai dan konsumennya adalah para pengguna lulusan, maka permasalahan ini tidak jauh dari konsep jasa pelayanan. Keberhasilan suatu jasa pelayanan untuk mencapai tujuannya sangat bergantung pada konsumen atau pengguna jasa. Ketika penyedia jasa pelayanan memberikan layanan yang bermutu kepada pelanggannya dapat dikatakan penyedia jasa tersebut telah sukses dalam mencapai tujuannya. Definisi mutu layanan berpusat pada upaya pemenuhan kebutuhan dan keinginan pelanggan serta ketepatan penyampaian untuk mengimbangi harapan pelanggan. Kualitas jasa adalah tingkat keunggulan yang diharapkan dan pengendalian atas tingkat keunggulan tersebut untuk memenuhi keinginan pelanggan. Mutu pelayanan 
diketahui dengan cara membandingkan harapan pelanggan atas layanan yang ideal dengan layanan yang benar-benar mereka terima. Jika jasa pelayanan yang diterima atau dirasakan sesuai dengan yang diharapkan, maka mutu pelayanan yang dipersepsikan baik dan memuaskan. Jika pelayanan jasa yang diterima melampaui harapan pelanggan maka mutu pelayanan dipersepsikan sebagai mutu yang ideal. Sebaliknya, jika pelayanan yang diterima lebih rendah daripada yang diharapkan, maka mutu pelayanan dipersepsikan buruk. Dengan demikian, baik tidaknya kualitas jasa bergantung pada kemampuan penyedia jasa dalam memenuhi harapan/kepentingan pelanggannya secara konsisten (Undana, 2014).

Berdasarkan buku katalog PTI (2013), Jurusan Pendidikan Teknik Informatika (PTI) Universitas Pendidikan Ganesha (Undiksha) Singaraja berdiri sejak tahun 2007. Jurusan PTI merupakan jurusan pencetak tenaga pengajar bidang studi Teknologi Informasi dan Komunikasi (TIK) dan tidak menutup kemungkinan mencetak tenaga kerja di instansi, perusahaan atau organisasi yang bergerak di bidang TIK. Sejauh ini, jurusan PTI sudah mencetak lebih dari 300 lulusan yang telah digunakan pengguna, dalam hal ini adalah Sekolah Menengah Kejuruan (SMK), Sekolah Tinggi, perusahaan swasta, pemerintah daerah dan lain sebagainya. Untuk mendapatkan gambaran tentang mutu layanan, dalam hal ini adalah layanan penyediaan luaran yang dihasilkan PTI Undiksha berupa lulusan, tindakan yang perlu dilakukan adalah menganalisis kepuasan pengguna lulusan dalam bentuk survey deskriptif. Survey ini akan menghasilkan persepsi pengguna lulusan yang dapat dijadikan refleksi diri Jurusan PTI Undiksha untuk memberikan luaran yang lebih berkualitas dan bermutu.

\section{METODE PENELITIAN}

Metode penelitian meliputi prosedur penelitian, lokasi penelitian, populasi dan sampel penelitian, instrumen penelitian beserta teknik pengumpulan dan analisis data.

Menurut Arikunto(1998) dan Hadi (1998), Prosedur penelitian dimulai dengan mengidentifikasi masalah, merumuskan masalah, menentukan tujuan dan manfaat, menentukan kajian teori atau studi pustaka, mendesain metode penelitian, melakukan pengambilan data, menganalisis data, dan pembuatan laporan penelitian. Lokasi penelitian merupakan tempat dimana penelitian akan dilakukan. Penelitian ini akan dilaksanakan di Jurusan Pendidikan Teknik Informatika dan di tempat para alumni jurusan Pendidikan Teknik Informatika bekerja. Populasi dari penelitian ini adalah seluruh alumni Jurusan Pendidikan Teknik informatika dan seluruh stakeholder dari lulusan. 
Dalam penelitian ini, data akan dianalisis secara kualitatif dan kuantitatif. Menurut Arikunto (2009) dan Kerlinger (2000), analisis kualitatif dalam penelitian ini bertujuan untuk mendeskripsikan kualitas alumni terkait dengan pengguna lulusan. Hasil analisis kualitatif berupa deskripsi atau gambaran mengenai kualitas alumni terkait dengan pengguna lulusan Pendidikan Teknik Informatika UNDIKSHA. Selain itu, karena penelitian ini merupakan penelitian deskriptif, maka analisis kuantitatif disini bertujuan untuk memperoleh persentase dari hasil kuesioner yang nantinya akan dianalisis secara deskriptif. Medly (1984) dan Sugiyono (2008) berpendapat, untuk menafsirkan besar persentase yang diperoleh dari tabulasi data, peneliti menggunakan metode penafsiran. Seperti metode penafsiran menurut (Supardi, 1979) seperti rentangan 1-25\% menunjukkan sebagian kecil, 26-49\% menunjukkan hampir setengah50\% menunjukkan setengahnya 51-75 menunjukkan sebagian besar, dan 76-99\% menunjukkan pada umumnya.

\section{HASIL DAN PEMBAHASAN}

Adapun hasil penelitian survey kualitas lulusan Jurusan Pendidikan Teknik Informatika Undiksha meliputi gambaran persebaran lulusan/alumni dan relevansi kurikulum terhadap kebutuhan dunia kerja.Gambaran persebaran alumni dapat dilihat dari lokasi bekerja, waktu tunggu kerja, penilaian lulusan terhadap aspek-aspek pembelajaran yang dimiliki Jurusan PTI, relevansi kompetensi yang dimiliki lulusan terhadap kebutuhan dunia kerja, dan relevansi peran jurusan terhadap kompetensi yang dimiliki lulusan terhadap kebutuhan dunia kerja.

Data lulusan yang berhasil dihimpun berasal dari 5 sekolah yaitu SMK Negeri 3 Singaraja, SMK Negeri 1 Sukasada, SMK Negeri 2 Seririt, SMA Negeri 2 Banjar, dan SMP Negeri 3 Melaya. Jumlah lulusan yang terkumpul dari sekolah-sekolah tersebut adalah 14 orang. Gambar 1 menunjukkan tentang persentase lulusan memperoleh informasi tempat kerja. Terlihat pada gambar, 7 orang atau 50\% menjawab dari teman, 3 orang atau $21 \%$ menjawab browsing melalui internet, 2 orang atau $14 \%$ menjawab dari keluarga dan 2 orang atau $14 \%$ menjawab dari pengguna kerja.

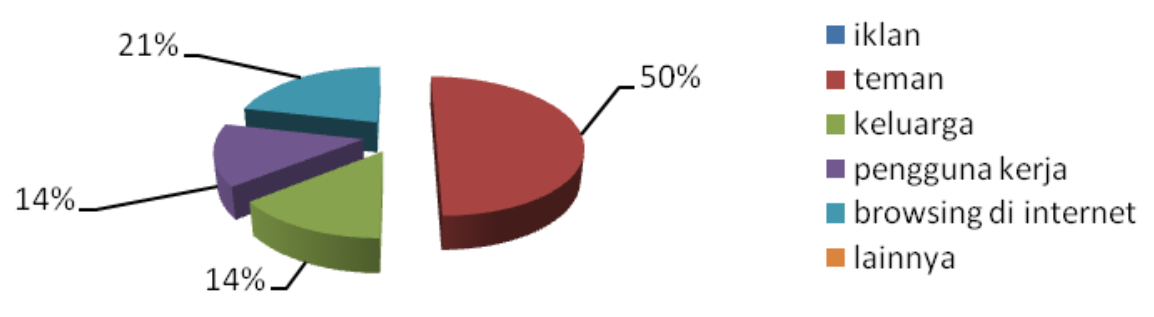

Gambar 1 Persentase lulusan memperoleh informasi tempat kerja 
Adapun aspek yang menjadi pertimbangan para alumni dalam memilih tempat bekerja adalah gaji, jarak dengan tempat tinggal/rumah, tantangan pekerjaan, keuntungan, dan kesempatan meraih beasiswa. Aspek tersebut terlihat pada Gambar 2 yang menyatakan seluruh responden (14 orang atau 100\%) setuju dengan aspek-aspek tersebut.

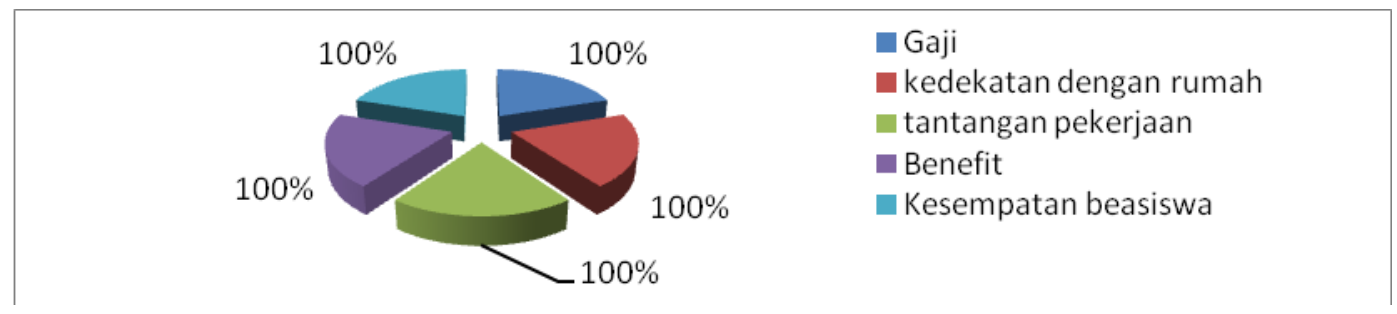

Gambar 2 Persentase aspek yang menjadi pertimbangan memilih pekerjaan

Cara yang ditempuh lulusan dalam mendapatkan pekerjaan terlihat pada Gambar 3 yang menunjukkan 4 orang atau $29 \%$ diminta oleh pengguna, 3 orang atau $21 \%$ mendapatkan rekomendasi, 2 orang atau 14\% memanfaatkan koneksi, 1 orang atau 7\% mendapatkannya dari berkompetisi, sisanya (29\%) menempuh caranya masing-masing.

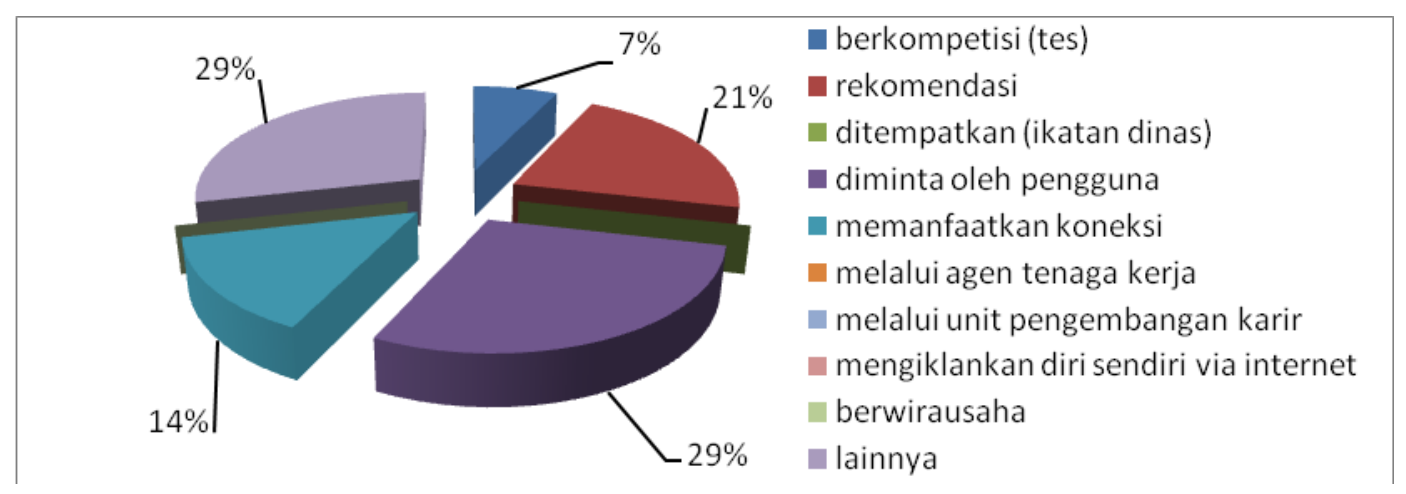

Gambar 3 Persentase cara lulusan memperoleh pekerjaan

Waktu tunggu kerja adalah lama waktu yang ditempuh lulusan mulai dari lulus studi sampai pertama kali mendapatkan pekerjaan. Gambar 4 menunjukkan perolehan waktu tunggu kerja oleh lulusan yang menunjukkan 6 orang atau $43 \%$ menunggu kurang dari 3 bulan, 5 orang atau $36 \%$ sudah bekerja sebelum lulus, dan 3 orang atau $21 \%$ dalam rentangan 3 sampai 6 bulan. 

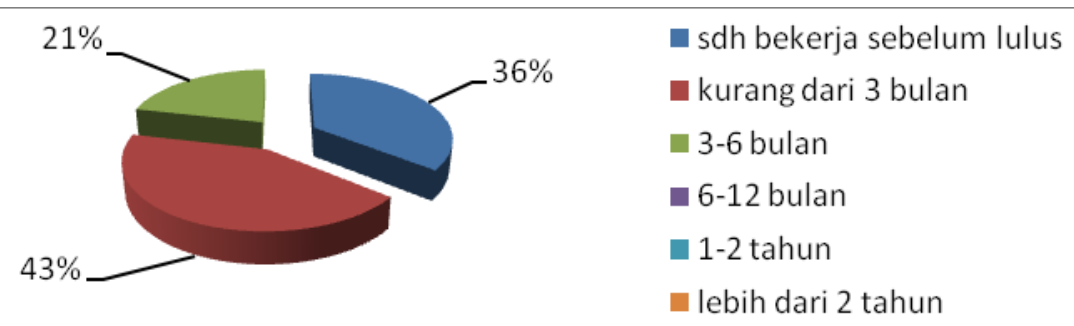

Gambar 4 Persentase lama lulusan menunggu pekerjaan

Relevansi kurikulum terhadap kebutuhan dunia kerja secara deskriptif ditinjau dari angket yang diberikan ke pengguna lulusan. Pengguna lulusan adalah para stakeholder seperti Kepala Sekolah, Waka Kurikulum, Ketua Program Studi SMK. Jumlah pengguna lulusan yang terkumpul adalah 8 orang. Angket yang disebar berupa angket pernyataan dan masukan atau saran dari pengguna lulusan. Adapun hasil dari angket tersebut adalah sebagai berikut.

Menurut bidang yang dikelola, terlihat bahwa seluruh lulusan (100\%) yang dijangkau oleh angket (14 orang) bekerja pada sektor pendidikan yaitu SMK Negeri 3 Singaraja, SMK Negeri 1 Sukasada, SMK Negeri 2 Seririt, SMA Negeri 2 Banjar, dan SMP Negeri 3 Melaya. Persentase kinerja lulusan pada sektor tersebut dapat dilihat pada Gambar 5 di mana 6 responden atau 75\% pengguna lulusan menyatakan sangat baik, sedangkan 2 responden atau $25 \%$ menyatakan sangat baik.

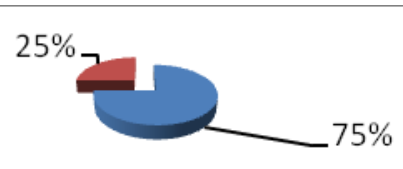

Sangat Baik
Baik
Sedang
Jelek

Gambar 5 Persentase kinerja lulusan

Ditemukan juga bahwa bidang-bidang yang dikuasai oleh lulusan meliputi komunikasi dan presentasi sebanyak 25\%, kepemimpinan sebanyak 50\%, dan bekerjasama dalam tim sebanyak 25\% yang dapat dilihat pada Gambar 6.

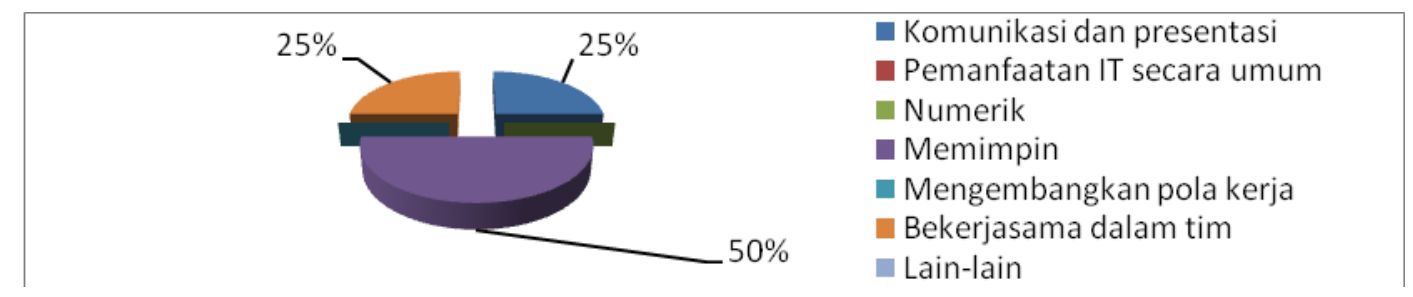

Gambar 6 Persentase bidang yang dikuasai oleh lulusan menurut pengguna lulusan 
Adapun saran/masukan dari pengguna lulusan dalam bentuk tertulis adalah sebagai berikut.

1. Mata kuliah yang dipandang perlu untuk diberikan meliputi animasi digital 2D dan 3D, administrasi server, instalasi WAN, jaringan komputer, komputer grafis, dan pengembangan web design.

2. Memberikan ilmu tambahan yang dibutuhkan di dunia kerja agar tidak bingung pada saat terjun ke dunia kerja.

3. Penyesuaian kurikulum Jurusan PTI dengan kurikulum nasional yang diterapkan di SMK bidang keahlian TI.

4. Penyesuaian laboratorium dengan kondisi globalisasi saat ini.

5. Penyesuaian laboratorium dengan mata pelajaran yang ada di SMK/SMA agar dapat diakomodir dengan baik oleh lulusan, seperti laboratorium animasi.

6. Penyesuaian kompetensi dosen agar sesuai dengan bidangnya.

7. Revisi terhadap kurikulum agar lebih menanamkan konsep agar mahasiswa menjadi paten dan lebih baik.

8. Kemudahan dalam pengurusan administrasi oleh lulusan.

9. Peningkatan pelayanan administrasi.

Dilihat dari sudut pandang pengguna lulusan, ditemukan bahwa relevansi kurikulum terhadap kebutuhan dunia kerja masih belum relevan. Hal ini tercermin pada banyaknya masukan atau saran yang diberikan pengguna lulusan ke pihak jurusan terkait pembenahan kurikulum.

Masukan atau saran mencakup pengadaan beberapa mata kuliah yang dipandang perlu sebagai penunjang kompetensi lulusan pada saat menapaki dunia kerja sesungguhnya. Penyesuaian kurikulum antara kurikulum yang dimiliki jurusan saat ini dengan kurikulum yang diterapkan pada SMK bidang keahlian TI juga mendapat sorotan. Hal ini terjadi pada saat lulusan diandalkan untuk menyelesaikan beberapa permasalahan di SMK seperti pendampingan lomba-lomba antar SMA atau SMK. Para lulusan sangat diandalkan untuk menjadi pembina lomba sesuai dengan bidang keahlian atau kompetensinya. Namun hal ini belum maksimal terjadi dikarenakan ilmu yang didapat oleh para lulusan belum sepenuhnya sinkron dengan permintaan pihak sekolah. Pembenahan kurikulum belum menyasar pada pembentukan konsep lulusan sehingga esensi dari setiap mata kuliah belum maksimal jika dibandingkan dengan beban yang ditanggung lulusan pada saat harus mengasuh siswa-siswa.

Penyesuaian laboratorium juga menjadi kendala para lulusan dalam mengembangkan kompetensinya. Fasilitas laboratorium yang belum sepenuhnya dapat 
menjadi kontributor dan fasilitator menjadi sumber masalahnya. Ketidaksesuaian penggunaan laboratorium dengan mata pelajaran yang diberikan di SMK/SMA adalah pemicunya. Mereka, para pengguna lulusan, mengharapkan adanya kesesuaian antara mata pelajaran yang diadakan di laboratorium dengan mata kuliah praktikum yang didapat di jurusan.

Terkait dengan masalah administrasi, pihak pengguna lulusan sangat mengharapkan pembenahan. Terlebih pada saat para pengguna lulusan akan mengurus masalah administrasi. Peningkatan pelayanan administrasi tentunya menjadi solusi agar birokrasi administrasi menjadi lebih mudah dan tidak cenderung berbelit-belit.

Pembahasan dari sudut pandang lulusan dibagi menjadi dua perspektif atau sudut pandang yaitu (1) Penilaian lulusan terhadap aspek-aspek pembelajaran yang dimiliki Jurusan PTI dan (2) Relevansi peran jurusan terhadap kompetensi yang dimiliki lulusan terhadap kebutuhan dunia kerja.

Pada perspektif penilaian lulusan dilihat dari sudut pandang pembelajaran yang dimiliki Jurusan PTI, terdapat beberapa butir yang menjadi sorotan karena memiliki nilai kurang bahkan sangat kurang yaitu pada perspektif partisipasi lulusan dalam riset Dosen. Sewaktu lulusan menjadi mahasiswa, mereka memandang kurangnya keterlibatan antara mahasiswa dengan para dosen dalam melakukan penelitian. Keterlibatan itu hanya terjadi pada saat mahasiswa membuat skripsi. Sedangkan pada saat dosen melakukan penelitian, mahasiswa sangat jarang dilibatkan. Tentunya ini menjadi catatan bagi jurusan agar lebih melibatkan mahasiswa dalam setiap kegiatan riset yang dilakukan dosen-dosen di jurusan. Hal ini akan memberikan pengalaman dan ilmu di luar konteks perkuliahan secara tidak langsung.

Selanjutnya, dilihat dari sudut pandang kesempatan di dalam ikut menentukan kebijakan. Dalam merumuskan segala bentuk kebijakan terkait dengan ke mana arah jurusan nanti, lulusan mengharapkan kesempatan dalam berpartisipasi. Selain itu, kesempatan untuk berinteraksi dengan dosen dirasa kurang. Di sini jurusan harus dapat lebih terbuka terhadap semua aktivitas dan kegiatan kepada lulusan.

Ketersediaan fasilitas penunjang belajar seperti ketersediaan kantin, layanan kesehatan, fasilitas rekreasi dan olah raga dan pusat kegiatan mahasiswa berikut fasilitasnya masih dinilai kurang oleh lulusan. Hal-hal yang dinilai kurang inilah yang akan menjadi acuan pembenahan jurusan dalam rangka membentuk lulusan-lulusan selanjutnya yang lebih kompeten di dunia kerja.

Pada perspektif relevansi peran jurusan terhadap kompetensi yang dimiliki lulusan terhadap kebutuhan dunia kerja didapat beberapa kekurangan yaitu kompetensi yang 
dikuasai lulusan dilihat dari sudut pandang pengetahuan di luar bidang ilmu. Hal ini terjadi karena kurangnya kegiatan ekstra yang berbau pendidikan dan pengembangan kompetensi seperti pelatihan sertifikasi terhadap kompetensi lulusan. Kegiatan-kegiatan di jurusan lebih banyak ke kegiatan organisasi yang dirasa belum seimbang antara organisasi dan pengembangan kompetensi.

Keterampilan riset juga menjadi butir yang dinilai kurang. Hal ini terjadi lantaran banyak dosen ketika melakukan penelitian tidak melibatkan mahasiswanya. Sehingga praktis pengalaman mahasiswa dalam bidang riset hanya sebatas pada pengerjaan skripsi.

Selain itu, beberapa sikap yang kurang dari lulusan ketika berada di dunia kerja adalah kemampuan bernegosiasi, kemampuan menganalisis, bekerja di bawah tekanan, toleransi, berpikir kritis, kepemimpinan dan kemampuan beradaptasi di lingkungan kerja yang berbeda termasuk pada saat bekerja dengan rekan yang memiliki kebudayaan yang berbeda.

\section{PENUTUP}

Simpulan yang dapat dibentuk dari pemaparan sebelumnya adalah sebagai berikut.

1. Berdasarkan respon dari pengguna lulusan terhadap kualitas lulusan secara menyeluruh, didapat bahwa kualitas lulusan berada pada rentangan baik. Hal ini dapat dilihat dari aspek lokasi bekerja, waktu tunggu kerja, penilaian lulusan terhadap aspek-aspek pembelajaran yang dimiliki Jurusan PTI, relevansi kompetensi yang dimiliki lulusan terhadap kebutuhan dunia kerja, dan relevansi peran jurusan terhadap kompetensi yang dimiliki lulusan terhadap kebutuhan dunia kerja yang kesemuanya rata-rata pada rentangan baik.

2. Meskipun memiliki kualitas baik, ada beberapa masukan dari pengguna lulusan terkait pembenahan kurikulum, pengadaan laboratorium, pengadaan mata kuliah yang sesuai dengan permintaan pengguna, dan pembenahan administrasi.

\section{DAFTAR PUSTAKA}

Arikunto. 1998. Prosedur Penelitian Suatu Pendekatan Praktek. Jakarta: Rineka Cipta.

Arikunto. 2009. Dasar-dasar Evaluasi Pendidikan. Jakarta: Bumi Aksara.

Hadi. 1998. Statistika Jilid 3. Yogyakarta: Andi.

Kerlinger. 2000. Asas-asas Penelitian Behavioral(Edisi Ketujuh), diterjemahkan Simatupang L.R. Yogyakarta: Gadjah Mada University Press. 
Medly. 1984. Measurement Based Evaluation of Teachers Performance. New York: Long Man.

Mutaqin. 2009. Peningkatan Kualitas Pendidikan Di Perguruan Tinggi Dilakukan Melalui Penyiapan Tenaga Dosen Bermutu Secara Berkelanjutan. Disampaikan sebagai Makalah Pendamping, pada Seminar Nasional "Penyiapan Tenaga Pendidik Profesional”. Program PHKI UNY, 20 Juni 2009 di Yogyakarta.

PTI. 2015.Katalog Jurusan Pendidikan Teknik Informatika. Singaraja: Undiksha.

Sugiyono. 2008. Statistika untuk Penelitian. Bandung: Alfabeta.

Supardi. 1979. Statistik. Bandung: Fakultas Tarbiyah IAIN Sunan Gunung Jati.

Undana. 2014. Laporan Kepuasan Pelanggan Eksternal. Penfui: Universitas Nusa Cendana. 